\title{
Hiponatremia in the practice of a psychiatrist. Part 1: SIADH syndrome and drug-induced hyponatremia.
}

\author{
Hiponatremia w praktyce lekarza psychiatry. \\ Część 1: zespół SIADH i hiponatremia polekowa
}

\author{
Ewa Stelmach ${ }^{1}$ ABDEF, Olga Hołownia ${ }^{1}$ BDEF, Maciej Słotwiński ${ }^{1}{ }_{\text {BDEF, }}$ \\ Aneta Gerhant ${ }^{1} \mathrm{BDEF}$, Marcin Olajossy ${ }^{1} \mathrm{DF}$
}

\author{
$12^{\text {nd }}$ Department of Psychiatry and Psychiatric Rehabilitation, Medical University of Lublin
}

\begin{abstract}
Introduction. Hyponatremia is an important part of psychiatric practice. In order to analyze its causes and symptoms, the literature on hyponatremia in psychiatric patients has been reviewed. The work has been divided into two separate manuscripts. In the first one the authors discuss the syndrome of inappropriate antidiuretic hormone secretion (SIADH) and hyponatremia occurring with the use of psychotropic drugs (antidepressants, antipsychotics, normotimics), while the second paper discusses research on psychogenic polydipsia. The causes of hyponatremia in patients treated in psychiatric wards include: water intoxication associated with polydipsia, somatic comorbidities, side effect of internal medicine and psychiatric drugs. The most common mechanism leading in these cases to hyponatremia is the syndrome of inappropriate secretion of vasopressin (SIADH). The SIADH syndrome is a group of symptoms, first described in 1967 by Schwartz and Bartter in The American Journal of Medicine, which results from the hypersecretion of antidiuretic hormone, also called vasopressin, which causes patients to develop normovolemic hyponatremia. The phenomenon of drug-induced hyponatremia in psychiatric practice is generally observed with the use of antidepressants, antipsychotics and anti-epileptic drugs (used in psychiatry as normotimic drugs).

Aim and method. The first manuscript includes a review of literature on the syndrome of inappropriate secretion of vasopressin (SIADH) and hyponatremia occurring after the use of psychotropic drugs, and is divided into two subsections: 1 . The syndrome of inappropriate secretion of vasopressin (SIADH), 2. Hyponatremia and psychotropic drugs (antidepressants, antipsychotics, normotimics).

Conclusion. In the view of the reviewed literature it is extremely important to control the natremia level during pharmacotherapy using the above mentioned drugs, especially in the initial period of therapy.
\end{abstract}

Keywords: hyponatremia, SIADH syndrome, drug-induced hyponatremia

\section{Streszczenie}

Wstęp. Hiponatremia jest istotnym zjawiskiem w praktyce psychiatrycznej. W celu przeanalizowania jej przyczyn oraz objawów, dokonano przeglądu literatury dotyczącej hiponatremii u pacjentów leczonych z rozpoznaniem zaburzeń psychicznych. Pracę podzielono na dwa osobne artykuły. W pierwszym autorzy omówili zespół nieadekwatnego wydzielania wazopresyny (SIADH) oraz zjawisko hiponatremii pojawiającej się po zastosowaniu leków psychotropowych (leków przeciwdepresyjnych, leków przeciwpsychotycznych, leków normotymicznych), natomiast w drugim artykule dokonano przeglądu badań dotyczących polidypsji psychogennej. Wśród przyczyn hiponatremii u pacjentów leczonych w oddziałach psychiatrycznych najczęściej wyróżnia się: zatrucie wodne związane z polidypsją, współwystępowanie chorób somatycznych, działanie niepożądane leków internistycznych i psychiatrycznych. Najczęstszym mechanizmem doprowadzającym w tych przypadkach do hiponatremii jest zespół nieadekwatnego wydzielania wazopresyny (zespół SIADH). Zespół SIADH to zespół objawów, po raz pierwszy opisany w 1967 przez Schwartza i Barttera w The American Journal of Medicine, który powstaje przy nadmiernym uwalnianiu hormonu antydiuretycznego, zwanego też wazopresyną, co powoduje u pacjentów rozwój hiponatermii normowolemicznej. Zjawisko hiponatremii polekowej w praktyce lekarza psychiatry jest najczęściej obserwowane po zastosowaniu leków przeciwdepresyjnych, leków przeciwpsychotycznych oraz leków przeciwpadaczkowanych (stosowanych w psychiatrii jako leki normotymiczne).

Cel i metoda. W pierwszym artykule dokonano przeglądu literatury, dotyczącej zespołu nieadekwatnego wydzielania wazopresyny (SIADH) oraz zjawiska hiponatremii pojawiającej się po zastosowaniu leków psychotropowych, dzieląc go na dwa podrozdziały: 1. Zespół nieadekwatnego wydzielania wazopresyny (SIADH), 2. Hiponatremia a leki psychotropowe (leki przeciwdepresyjne, leki przeciwpsychotyczne, leki normotymiczne).

Podsumowanie. W kontekście dokonanego przeglądu literatury niezwykle ważnym wydaje się być kontrola poziomu natremii podczas farmakoterapii wyżej wymienionymi lekami, szczególnie w początkowym okresie leczenia.

Słowa kluczowe: hiponatremia, zespół SIADH, hiponatremia polekowa

(C) 2017 Medical University of Lublin. This is an open access article distributed under the Creative Commons Attribution-NonComercial-No Derivs licence (http://creativecommons.org/licenses/by-nc-nd/3.0/) 
The literature on hyponatremia in patients treated for mental disorders has been reviewed. The work has been divided into two separate articles. In the first one we discuss the syndrome of inappropriate secretion of vasopressin (SIADH) and hyponatremia appearing after the antipsychotic drugs use (antidepressants, antipsychotics, mood stabilizers), the second article discusses current research studies on psychogenic polydipsia.

\section{Introduction}

Sodium is the major cation of extracellular fluid, responsible for the water-electrolyte and acid-base balance in the body. Maintenance of proper serum sodium levels is based on balanced supply and excretion of water regulated by the thirst center and the secretion of antidiuretic hormone [1]. Sodium and potassium regulate the osmotic pressure of body fluids and form the functional potential responsible for the conduction of nerve impulses as well as the contraction and relaxation of skeletal and cardiac muscles [2]. In addition, it enables the active transport of amino acids and carbohydrates to tissues via the sodium gradient [3]. Under physiological conditions, serum sodium levels are maintained between 135-145 mmol/l [4].

Hyponatraemia, defined as a serum sodium concentration $<135 \mathrm{mmol} / \mathrm{l}$, is the most common disorder of body fluid and electrolyte balance encountered in clinical practice [5] and may be caused by excessive consumption of water free of electrolytes by patients with impaired excretory renal function, excessive water intake [6] or disproportionately greater loss of sodium than water through the kidneys, gastrointestinal tract, skin [7]. Decrease in serum sodium concentrations creates an osmotic gradient between the extracellular and intracellular fluid in cerebral cells, causing penetration of water into the cells, increasing intracellular volume and, consequently, promotes tissue edema and neurologic symptoms [8].

Hyponatremia can be divided into mild, moderate and severe/profound depending on the serum sodium concentration [4] (Tab. 1).

Table 1. Division of hyponatremia according to serum sodium level

\begin{tabular}{|c|c|}
\hline Severity & Serum sodium level[mmol/l] \\
\hline mild & $130-135$ \\
\hline moderate & $125-129$ \\
\hline severe/profound & $<125$ \\
\hline
\end{tabular}

Mild hyponatremia (sodium concentration 130-135 mmol / l) is usually asymptomatic. With a drop in serum sodium level from 129 to $125 \mathrm{mmol} / \mathrm{l}$ (moderate hyponatremia), weakness, nausea, and vomiting may occur. In severe hyponatremia (sodium concentration $<125 \mathrm{mmol} / \mathrm{l}$ ), headache, nausea, vomiting, anorexia and orientation disorder may develop, and convulsions and coma [4,5] may occur with a drop below $110 \mathrm{mmol} / \mathrm{l}$.

Depending on the time of development, hyponatraemia can be acute and chronic (Tab. 2). This division determines the ways of natremia corrections. Hyponatremia, which develops in less than 48 hours, is defined as severe, and lasting more than 48 hours is defined as chronic [9]. In patients who cannot specify the duration of hyponatremia it should be understood as chronic hyponatremia [10].

Table 2. Definition of hyponatremia, depending on the time of development

\begin{tabular}{|c|c|}
\hline Definition & Duration \\
\hline acute & $<48 \mathrm{~h}$ \\
\hline chronic & $>48 \mathrm{~h}$ \\
\hline
\end{tabular}

Severe hyponatremia is associated with increased mortality as a result of rapid development of cerebral edema [11]. Chronic hyponatremia in the brain can trigger adaptive mechanisms that increase the excretion of electrolytes and organic matter into the extracellular space, resulting in loss of water and decreased edema [8].

Sodium ions are the major osmolit of the extracellular space, and their decrease in plasma causes hypotonia of extracellular fluid, hence hyponatremia and hyposmolality are used as synonyms [12].

Hyponatremia may occur in people showing evidence of dehydration or proper hydration or overhydration.

Having regard to intracellular water resources, hyponatremia can be divided into: hypovolemic, hypervolemic and normovolemic [6] (Tab. 3).

Hypovolemic hyponatremia is the result of simultaneous loss of water and sodium through the skin, digestive tract or kidneys. It can be caused by vomiting, diarrhea, pancreatitis, skin and mucosal burns, diuretics, nephropathy of salt loss and Addison's disease [12].

Hypervolaemic hyponatremia can occur in heart failure, cirrhosis with ascites, and in renal diseases nephrotic syndrome, acute or chronic renal failure. A common feature of this type of hyponatremia is the organ hypoperfusion despite the body overhydration. It leads through the baroreceptors to increased secretion of vasopressin and consequently further retention of water and hyponatremia severity [6].

Normovolemic hyponatremia occurs primarily in severe cases of hypothyroidism and the frontal lobe of the pituitary [13]. The cause of hyponatremia with normal hydration may also be excessive secretion of antidiuretic hormone, caused by ectopic ADH secretion in neoplastic diseases, hyperactivity of ADH secretion in patients with lung diseases, central nervous system diseases, and druginduced diseases $[4,14]$. 
Table 3. Division of hyponatremia with regard to body fluids volume

\begin{tabular}{|c|l|l|}
\hline Hyponatremia type & \multicolumn{2}{|c|}{ Causes } \\
\hline Hypovolemic & $\begin{array}{l}\text { Renal water and sodium wasting: } \\
\text { use of diuretics } \\
\text { salt-using nephropathy } \\
\text { osmotic diuresis } \\
\text { hypoaldosteronism } \\
\text { Gostrointestinal sodium loss (diarrhea, } \\
\text { vomiting, bowel obstruction - third } \\
\text { space wasting) } \\
\text { Transdermal sodium loss (burns) }\end{array}$ \\
\hline Normovolemic & $\begin{array}{l}\text { SIADH } \\
\text { Hypothyroidism } \\
\text { Adrenal insufficiency } \\
\text { Psychogenic polydipsia } \\
\text { Prolonged physical effort }\end{array}$ \\
\hline Hypervolemic & $\begin{array}{l}\text { Renal failure(Chronic kidney disease, nephritic syndrome) } \\
\text { Cirrhosis } \\
\text { CHF }\end{array}$ \\
\hline
\end{tabular}

However, there are two situations in which marked hyponatremia is not synonymous with the hypoosmolality. These are non hypotonic hyponatremia (isotonic or hypertonic) and pseudo hyponatremia [12]. The first one is due to the transport of water from the intracellular to the extracellular space due to increased plasma concentrations of osmotically active substances (such as glucose, mannitol, radiographic contrast media) [13]; pseudo hyponatremia occurs with hyperlipidemia, hyperglycemia, hyperuricemia or hyperproteinemia, which cause a relative plasma water phase decrease. Each measured plasma volume contains less sodium ions in this case, resulting in false serum sodium levels $[12,15]$.

Among the causes of hyponatremia in patients treated in psychiatric wards there are mostly distinguished:

- water poisoning associated with polydipsia

- co-occurrence of somatic diseases

- adverse effects of internal medicine and psychiatric drugs [16].

The most common mechanism leading in these cases to hyponatremia is the syndrome od inappropriate antidiuretic hormone (vasopressin) secretion (SIADH) [16].

\section{Aim and method}

The first article, reviews literature (in Google Scholar and PubMed databases) on the inappropriate secretion of vasopressin (SIADH) and hyponatremia occurring after administration of psychotropic drugs The review of literature is divided it into two subsections:

1. Inappropriate anti-diuretic hormone (vasopressin) secretion syndrome (SIADH),

2. Hyponatremia and psychotropic drugs (antidepressants, antipsychotics, normotimics).

\section{Syndrome of inappropriate secretion of anti- diuretic hormone (vasopressin) (SIADH),}

SIADH is a group of symptoms, first described in 1967 by Schwartz and Bartter in The American Journal of
Medicine [17], which results from the excessive secretion of the antidiuretic hormone (ADH), also called vasopressin, which results in developing normo- volemic hiponatremia in patients [18].

\section{Pathogenesis}

There are four basic types of SIADH, depending on the vasopressin secretion model:

1) Type A, most common, reported in $40 \%$ of cases, is usually described in patients with small cell lung carcinoma, secreting ectopic vasopressin. ADH is therefore secreted in a completely unregulated manner by plasma osmolality. Despite the decrease in plasma osmolality, ADH secretion remains unstoppable and severe hyponatremia may develop if the patient continues to take fluids [19]. In this type of SIADH, the threshold plasma osmolality, which causes inhibition of the thirst, is lower than usual, causing that hypotonatremia in the patient will not be corrected by self-limitation of fluid intake [20].

2) Type B, in which the linear relationship between plasma osmolality and vasopressin secretion is maintained, but the threshold plasma osmolality that inhibits vasopressin secretion is lower than physiologically. Thus, the natremia level, which reaches stable values, is usually lowered, usually between 125 and $135 \mathrm{mmol} / \mathrm{l}$ [19].

3) Type C, a rare variant of SIADH, where with plasma osmolality of more than $284 \mathrm{mOsm} / \mathrm{kg}$, the linear relationship between plasma osmolality and vasopres$\sin$ concentration is maintained. However, when plasma osmolality drops below $284 \mathrm{mOsm} / \mathrm{kg}$, reduced plasma osmolality does not suppress the secretion of ADH. This is probably due to impairment in the inhibitory hypothalamic neuronal function. Low vasopressin values are continuously detectable in plasma [19].

4) Type D, the least common SIADH variant in which formal criteria for diagnosis of this syndrome are met but plasma $\mathrm{ADH}$ level is undetectable. This may be due to the production of other antidiuretic factors by tumor cells, or muta- 
tion of V2 receptors for vasopressin in renal tubules, which causes them to be permanently activated [19].

\section{Diagnostic criteria}

The SIADH diagnostic criteria described for the first time by Schwartz and Bartter have changed over the years and evolved with new discoveries and a fuller understanding of the causes of this syndrome. The current criteria of European Renal Association - European Dialysis and Transplant Association (ERA-EDTA) are presented in Table 4 [5]. All major criteria must be met to identify the syndrome. If all the main criteria are not met, the presence of supportive criteria increases the probability of SIADH syndrome. Previously among the additional criteria, elevated blood vasopressin level was mentioned, but this is currently not recommended, mainly due to the technical difficulty of its determination and interpretation of the results, due to the varying relationship between plasma concentrations of $\mathrm{ADH}$ and the loss of free water and electrolytes [5].

Table 4. Diagnostic criteria of SIADH (adapted from Spasovski, G. et al.) [5]

\begin{tabular}{l} 
Essential criteria: \\
Effective serum osmolality $<275 \mathrm{mOsm} / \mathrm{kg}$ \\
Urine osmolality $>100 \mathrm{mOsm} / \mathrm{kg}$ \\
Clinically assessed euvolemia \\
Urine sodium concentration $>30 \mathrm{mmol} / \mathrm{l}$ with normal \\
dietary sodium and water intake \\
Absence of adrenal, thyroid, pituitary or renal \\
insufficiency \\
Not recent use of thiazide diuretics \\
\hline Supporting diagnostic criteria: \\
Serum uric acid level $<0.24 \mathrm{mmol} / \mathrm{l}(<4 \mathrm{mg} / \mathrm{dl})$ \\
Serum urea level $<3.6 \mathrm{mmol} / \mathrm{l}(<21.6 \mathrm{mg} / \mathrm{dl})$ \\
Failure to correct or worsening of hyponatremia after \\
$0.9 \%$ NaCl infusion \\
Fractional sodium excretion $>0.5 \%$ \\
Fractional urea excretion $>55 \%$ \\
Fractional uric acid excretion $>12 \%$ \\
Correction of hyponatremia through fluid restriction
\end{tabular}

It should be emphasized that SIADH is a diagnosis of exclusion. In addition to adrenal, thyroid, pituitary and renal failure, chronic hypovolaemia and hyponatremia should be excluded [5].

The clinical picture of SIADH includes typical symptoms of hyponatremia, such as headache, nausea, vomiting, muscle cramps, anxiety, deep drowsiness, confusion, weakness of the reflexes. The consequence of rapidly developing hyponatremia can be cardio-respiratory failure, herniation of the brain stem and death [21].

\section{Causes}

The causes which may induce the syndrome of inappropriate secretion of vasopressin are very varied (Tab. 5).
According to various sources, the most common cause of SIADH are cancers, CNS diseases or drugs $[22,23,24]$.

Tabele 5. The causes of SIADH (adapted from: Cuesta et al.[19] i Verbalis et al.[12])

\begin{tabular}{|l|}
\hline Malignancies: \\
Lung / mediastinum (lung cancer, pleural mesothelioma, \\
Other (duodenal cancer, pancreatic cancer, prostate can- \\
cer, endometrial cancer, nasopharyngeal carcinoma, leu- \\
kemia, lymphoma, sarcoma) \\
\hline Disorders of the CNS \\
Massive damage (tumors, abscesses, hematomas) \\
Inflammatory diseases (encephalitis, meningitis, lupus, \\
acute intermittent porphyria) \\
Neurodegenerative and demyelinating diseases (Guillain- \\
Barre disease, multiple sclerosis)Miscellaneous (subarach- \\
noid haemorrhage, acute psychosis, delirium tremens, hydro- \\
cephalus, vasculitis, cavernous sinus thrombosis) \\
\hline Medications \\
Stimulation of ADH secretion (nicotine, phenothiazine \\
derivatives, tricyclic antidepressants) \\
Renal effects or potential antidiuretic effect of ADH (desmo- \\
pressin, oxytocin, prostaglandin synthesis inhibitors) \\
Multifactorial or unknown effects (angiotensin convert- \\
ing enzyme inhibitors, carbamazepine, clofibrate, clozap- \\
ine, cyclophosphamide, 3,4- \\
methylenedioxymethamphetamine ["Ecstasy"], omepra- \\
zole, serotonin reuptake inhibitors, vincristine) \\
\hline Lung diseases \\
Infections (tuberculosis, pneumonia, aspergillosis, pleu- \\
ral abscess, bronchiectasis) \\
Other (acute respiratory failure, chronic obstructive \\
pulmonary disease, mechanical ventilation with positive \\
pressure) \\
\hline Other \\
Acquired immunodeficiency syndrome AIDS \\
Prolonged strained physical exercise (marathon, triathlon, etc) \\
Giant cellular vasculitis \\
Idiopathic \\
\hline
\end{tabular}

The first description of SIADH dating back to 1967 involved a patient suffering from lung cancer [17]. This cancer can cause the syndrome of inappropriate secretion of vasopressin in almost $15 \%$ of the cases [22].

The course of SIADH varies depending on the cause. SIADH caused by central nervous system diseases often has a more severe course compared to the syndrome of inadequate diuresis induced by other pathologies. The etiology is also an important factor influencing the prognosis of quick balancing of natremia. In SIADH induced by potentially reversible causes, such as infection or medication, a return to normal natremia is easier than in the syndrome of inappropriate secretion of vasopressin having the cancer etiology [24].

\section{The management of SIADH}

The syndrome of inappropriate secretion of vasopressin should be treated causally, whenever possible. In 
the case of psychiatric patients, the cause-specific treatment of SIADH includes most commonly discontinuation of the drug,which caused electrolyte abnormalities [22]. According to many reports [22, 25], this is often a sufficient method of treatment (in the case of SSRIs, approximately 2 weeks after the withdrawal of the drug, natremia is corrected) [25].

With chronic SIADH-induced hypoatremia, without severe or moderate symptoms, fluid restriction is recommended as the first-line treatment [5]. The volume of fluid intake should be lower by $500 \mathrm{ml}$ from the volume of urine excreted per day by the patient. Many patients react slowly to this treatment method and it takes several days to reach normalization of serum sodium levels [22].

Second-line therapy is to increase the supply of sodium, with urea administered orally at a dose of 0.25 to $0.5 \mathrm{~g} / \mathrm{kg} / \mathrm{b} . \mathrm{m} / \mathrm{d}$ or the use of sodium chloride orally in combination with the low-dose loop diuretic [5].

The recommendations for the use of demeclocycline in SIADH are divergent. Only in some countries it is registered for this indication [22], whereas European Societies do not recommend using it for the treatment of inadequate diuretics, as is the case with lithium [5]. Also reports on the use of vaptans, i.e. vasopressin receptor antagonists, are different. American researchers have published research results in the Clinical Journal of Medicine confirming that the use of vaptans in the treatment of SIADH may shorten the hospitalization [26], but according to the common position of the European Society for Intensive Care, European Endocrinology and the European Nephrology Association, vasopressin receptor antagonists, although increasing plasma levels, should not currently be recommended for the treatment of SIADH. It has been considered that the benefit-risk ratio of these substances is negative. The most important factor that limits the safety of vaptans use is the risk of rapid correction of natremia during their use and the associated risk of developing demyelinating syndrome [5].

It should be emphasized that during the treatment of SIADH, general recommendations for the treatment of hypotonic hyponatremia should always be followed. They are presented in Table 6 [5].

\section{Hyponatremia and psychotropic drugs (antidepres- sants, antipsychotics, normotimics)}

\section{SIADH and antidepressants}

There are many reports on the occurrence of hyponatremia following the use of selective serotonin reuptake inhibitors (SSRIs) [27]. Many studies confirm that SSRIs are the most common iatrogenic cause of hyponatremia [28], and that one in every 200 SSRI patients develops hyponatremia [29]. In 1988, Brownfield et al.
Table 6. SIADH treatment (adapted from: Spasovski, G. et al. [5])

Acute or chronic hyponatremia with severe symptoms treatment in the first hour

immediate administration of $150 \mathrm{ml} \mathrm{3 \%}$ hypertonic $\mathrm{NaCl}$ or equivalent over $20 \mathrm{~min}$.

determination of serum sodium concentration in each subsequent 20 minute of re-administration $150 \mathrm{ml} \mathrm{3 \%}$ hypertonic $\mathrm{NaCl}$ or equivalent

repeat the above recommendations until the serum sodium level is increased by $5 \mathrm{mmol} / \mathrm{l}$

Further treatment of hyponatremia after serum level increase by $5 \mathrm{mmol} / \mathrm{l}$ in the first hour and clinical improvement

- discontinue administration of the hypertonic $\mathrm{NaCl}$ solution

- start slow infusion of $0.9 \% \mathrm{NaCl}$ solution until the onset of causative treatment

- initiate causative treatment

- it is recommended that the correction of natremia in the first 24 hours of the treatment did not exceed $10 \mathrm{mmol} / \mathrm{l}$, and in the following days $8 \mathrm{mmol} / \mathrm{l}$, until the target value is $130 \mathrm{mmol} / \mathrm{l}$.

- control of serum sodium levels after 6 and 12 hours

Further treatment of hyponatremia after serum sodium increase by $5 \mathrm{mmol} / \mathrm{l}$ in the first hour, in the absence of clinical improvement

- Further administration of $3 \%$ hypertonic $\mathrm{NaCl}$ or equivalent to achieve an additional increase in natremia by $1 \mathrm{mmol} / \mathrm{l} / \mathrm{h}$. - stopping the infusion of $3 \%$ hypertonic saline or equivalent when the symptoms improve, the serum sodium concentration increases by $10 \mathrm{mmol} / \mathrm{l}$ in total or the serum sodium concentration reaches $130 \mathrm{mmol} / \mathrm{l}$, whichever occurs first

- extensive diagnostics

- checking serum sodium level every 4 hours

Treatment of hyponatremia with moderate symptoms - withdrawal of medication potentially intensifying hyponatremia

- cause-specific treatment

- administration of a single infusion of $150 \mathrm{ml}$ of 3\% hypertonic $\mathrm{NaCl}$ solution or equivalent over $20 \mathrm{~min}$.

- It is recommended that the increase of natremia in the first 24 hours did not exceed $10 \mathrm{mmol} / \mathrm{l}$, and in subsequent days 8 mmol / l, until reaching the target value $130 \mathrm{mmol} / \mathrm{l}$

- determination of serum sodium levels at 1, 6 and 12

hours of treatment

Treatment of acute hyponatremia without moderate or severe symptoms

- exclusion of pre-laboratory sampling error

- withdrawal of medication potentially intensifying hyponatraemia

- cause-specific treatment

- diagnosis of hyponatremia

- in case of sudden decrease in serum sodium level exceeding $10 \mathrm{mmol} / \mathrm{l}$, a $150 \mathrm{ml}$ of a $3 \% \mathrm{NaCl}$ solution should be administered within 20 minutes.

- determination of serum sodium level after 4 hours

Treatment of chronic hyponatremia without moderate or severe symptoms

- discontinue administration of fluids and drugs poten-

tially worsening hyponatremia

- cause-specific treatment

- in mild hyponatremia, treatment focused only on the increase of serum sodium is not recommended

- in moderate and severe hyponatremia, it is recommended that the increase of natremia in the first 24 hours did not exceed 10 $\mathrm{mmol} / \mathrm{l}$ and in the following days $-8 \mathrm{mmol} / \mathrm{l}$

- in moderate and severe hyponatremia serum sodium

level should be determined every 6 hours 
demonstrated that serotonin stimulates ADH secretion via 5HT2c, 5HT2a and 5HT7 receptors [30]. According to other studies, antidepressants not only increase the secretion of $\mathrm{ADH}$, but also increase the sensitivity of the kidneys to this hormone [31].

According to a retrospective study by Kirby et al., the risk of developing hyponatraemia in patients taking SSRIs or venlafaxine is 5.6 times greater than in patients not taking these antidepressants. In the same study, it was also shown that venlafaxine is more likely to have a hyponatremiaside effects than serotonin reuptake inhibitors [32]. This is probably due to the extra noradrenergic component of venlafaxine mechanism of action. Animal studies have shown that noradrenaline, like serotonin, increases vasopressin secretion [33, 34].

Leth-Moller et al. conducted a large retrospective cohort study in Denmark to estimate the risk of hyponatremia during treatment with antidepressants. The LABKA database was analyzed from 1998 to 2012 for hyponatremia. An event of hyponatremia occurred in 72,509 patients from the study group, which consisted of 638,352 people, and in $11.36 \%$, it occurred during therapy with antidepressants. The incidence rates were respectively: for citalopram 7.8, clomipramine 4.93, duloxetine 2.05 , venlafaxine 2.9 , mirtazapine 2.95 , mianserine 0.9 . This gives the grounds to say that all of these drugs, with the exception of mianserin, are associated with hyponatremia. The greatest risk is posed by citalopram therapy [35].

Among the antidepressants causing hyponatraemia, we can also mention MAO inhibitors and tricyclic antidepressants. In a study by Mannesse et al., the incidence of hyponatremia was slightly higher among patients taking TLPDs than with other antidepressants, but this difference was not statistically significant [31]. There are also reports of hyponatraemia associated with duloxetine use [36].

Not every patient treated with antidepressants is equally exposed to the development of hyponatremia. Giorlando et al., in a retrospective study from 2013, found that risk factors for hyponatremia following SSRI and SNRI were age $>65$ years, female sex and sertraline or escitalopram use [37]. Other risk factors for hyponatremia include past events of hyponatremia in the patient, body weight $<60 \mathrm{~kg}$, psychotic symptoms [31], female sex [25] and antidepressant combination with diuretics, angiotensin converting enzyme inhibitors (ACEI) or inhibitors of protonic pump (IPP) [34].

In most reports, hyponatremia develops at the beginning of drug use, with SSRI occurring most often between 3 and 120 days after initiation of treatment, on average on day 13. The highest risk occurs in the first month of treatment [38], with citalopram between day 6 and 20 on average [39]. Fabian et al. investigated the occurrence of hyponatremia in older patients after the administration of paroxetine. The study group consisted of 75 people aged 63 to 90 years. Natremia levels were monitored prior to initiation of paroxetine therapy, every week for the first 4 weeks followed by 1,2,3,4,6 and 12 weeks after initiation of therapy.

Hyponatremia developed in 9 out of 75 patients (12\%). The mean time from the onset of treatment to the development of electrolyte abnormalities was $9.3+/-4.7$ days [40]. However, the case was described when SIADH developed after 16 months of paroxetine inclusion [41]. Analysis of selected cases shows that after the use of antidepressants hyponatremia may develop suddenly, so it is advantageous to monitor electrolyte levels at the beginning of treatment $[38,39,41]$.

However, there are studies that suggest that SSRIs are not significantly associated with the development of hyponatremia in people at risk. Noohi et al. conducted a retrospective study of 239 inpatients. They were divided into three groups: patients taking SSRIs, patients taking other antidepressants and those who did not receive any antidepressant treatment. The greatest decrease in serum sodium levels did not differ statistically significantly in the test groups (SSRI - $3.31 \mathrm{mmol} / \mathrm{l}$, other antidepressants $3.41 \mathrm{mmol} / \mathrm{l}$, without antidepressant treatment - 3.13 mmol / l). In addition, the incidence of hyponatremia was not significantly different in the study groups [42].

\section{SIADH and antipsychotics}

The assessment of hyponatremia risk following classic and atypical neuroleptics use is currently based on many casuistic descriptions and no systematic research has been carried out in this area [43].

In 1997, Whitten and Ruehter described a case of a 48-year-old man with no history of endocrine disorder and no history of renal disease without diuretics, who developed symptomatic hyponatremia with convulsions, rhabdomyolysis, and respiratory distress seven days after risperidone inclusion. As a potential mechanism of hyponatremia, SIADH was diagnosed as a result of risperidone inclusion [44].

Atalay et al. described a case of 76-year-old man treated with escitalopram and quetiapine followed by citalopram and quetiapine. The treatment resulted in hyponatremia occurrence. After discontinuation of SSRIs, hyponatremia persisted, but remitted only a few days after quetiapine withdrawal, hence the atypical neuroleptic was considered the cause of the problem [46].

Hyponatremia as an undesirable drug effect was also reported with the use of olanzapine. Bakhla et al. described a case of a 63-year-old man diagnosed with a severe depressive episode with psychotic symptoms during recurrent depressive disorder, treated with escitalopram and olanzapine. Antidepressant therapy had 
been started two years earlier and no side effects were observed at that time, but after the inclusion of olanzapine, the patient developed symptomatic hyponatraemia, hence atypical neuroleptic therapy was also identified as the reason [46]. In turn, Dudeja et al., described the case of 48-year-old woman treated for two years with olanzapine at a dose of $20 \mathrm{mg}$ a day, who developed hyponatremia resulting in respiratory arrest. No other potential causes of hyponatremia were detected, and normalization of sodium levels has been observed after discontinuation of olanzapine [47].

Hyponatremia was also observed with the use of classic antipsychotics [48]: haloperidol [49] and thioridazine [50].

The phenomenon of drug-induced hyponatremia occurrence was also the subject of review and retrospective population studies.

Correll et al. reviewed literature to estimate the occurrence of adverse drug reactions following psychotropic drugs use in selected mental disorders, thus confirming reports of hyponatremia in the course of antipsychotic therapy [51].

Meulendijks et al. have made a systematic review of the literature on the occurrence of hyponatremia following the administration of antipsychotics, with particular regard to patient characteristics, neuroleptic dose, polydipsia, and SIADH [52]. The authors searched the MEDLINE and EMBASE databases between January 1966 and April 11, 2009, using the inclusion criteria, i.e. hyponatremia (natremia below $136 \mathrm{mmol} / \mathrm{l}$ ) after inclusion of neuroleptics therapy and the link between the use of neuroleptic and hyponatraemia as defined by WHO. The analysis of 4 studies and 91 case reports consistent with the inclusion criteria showed that both classic and atypical neuroleptics may be associated with druginduced hyponatraemia [52].

In their paper of 2010, Mannesse et al. analyzed the relationships between the use of atypical neuroleptics and hyponatraemia. Until August 2008, more than 3 million (3 881518 ) adverse drug reactions had been reported in the VigiBase database, of which 912 reported hyponatremia following neuroleptics use. The authors of that study noted that olanzapine and risperidone (and other atypical neuroleptics) were associated more frequently with the onset of hyponatraemia than other adverse side effects [53].

In turn, Gandhi et al. analyzed databases containing reports from health care systems for retrospective population-based cohort study of older patients aged 65 years and older from Ontario, Canada. The results of this analysis indicate that the use of atypical neuroleptics was associated with an increased 30-day risk of hospitalizations due to hyponatremia compared with not using neuroleptics $(0.15 \%$ vs. $0.09 \%)$; relative risk 1.62 , total risk increase of $0.06 \%$ [43].
Shepshelovich et al. also studied hyponatremia in patients taking different groups of medications: antidepressants, antipsychotics, antiepileptics, analgesics, cytostatics, and other drugs potentially associated with hyponatraemia. The authors examined 198 patients with SIADH, $73.7 \%$ of which were associated with medicationsinduced etiology. In order to differentiate the cause of SIADH, the Naranjo scale was used (1981), which assesses the probability of the occurrence of pharmacotherapy-induced hyponatremia. In this study, the drugs most commonly associated with SIADH were antidepressants, and risperidone dominated the neuroleptics (22 cases of SIADH) [54].

When analyzing the problem of hyponatremia in patients treated for psychotic disorders, two issues need to be distinguished: antipsychotic- and psychosis-induced hyponatremia, as described by Atsariyasing and Goldman [55]. The authors searched the MEDLINE database from 1960 to September 2012, taking into account the works previously analyzed by Meulendijks et al., using keywords: hyponatremia, SIADH, antipsychotics, and English. Initially, 186 articles were selected for further analysis, of which 39 were eventually analysed (54 patients treated in hospital). Naranjo' s scale was utilized to determine the probability of drug-induced hyponatremia (1981).These findings indicate that measures of urine concentration can help distinguish between antipsychotic-induced and psychosis-induced hyponatremia.

\section{SIADH and normothymic drugs}

Antiepileptic drugs used in psychiatry as normotimic drugs may also be the cause of drug-induced hyponatremias [56,57].

Kuz and Manssourian described the case of a 44year-old woman treated with carbamazepine. She developed acute hyponatremia after ingesting twice her evening dose of carbamazepine ( 2x600 mg). On admission, her serum sodium level was $122 \mathrm{mmol} / \mathrm{L}$. An infusion of $0.9 \% \mathrm{NaCl}$ was begun and carbamazepine was withheld, and within 24 hours, the serum sodium level returned to her previous level of $136 \mathrm{mmol} / \mathrm{L}$. The woman had experienced a similar event 6 months earlier when she also took a large dose of carbamazepine [58].

Krysiak and Okopień also described a case of iatrogenic, severe hyponatremia in a patient treated with carbamazepine. A 59-year-old man with trigeminal neuralgia was treated with carbamazepine initially at $200 \mathrm{mg} /$ day and then increased to $600 \mathrm{mg} /$ day in 2 divided doses. After 2 weeks, the patient had neurological symptoms and was admitted to hospital with suspected stroke. Laboratory studies showed a serum sodium concentration of 112 $\mathrm{mmol} / \mathrm{l}$. The clinical picture indicated SIADH syndrome. In the patient carbamazepine was discontinued, natremia 
was alleviated, and no electrolyte disturbances were observed in one-year follow-up examinations [59].

Kumar and Gopalakrishnan, have described cases of hyponatraemia occurring with oxcarbazepine (OXC). The first situation occurred in a 57-year-old man who did not take other medicines and had no significant medical comorbidities. Three weeks after starting OXC, he developed fatigue, vomiting, reduced appetite and food intake, difficulty in passing urine. Biochemical investigations revealed serum sodium of $115 \mathrm{mmol} / \mathrm{L}$, and after discontinuation of oxcarbazepine and administration of hypertonic saline, the serum sodium level returned to normal after 3 days. The second description concerned a 33-yearold woman who also took oxcarbazepine for bipolar disorder. One week after the start of treatment, symptoms of hyponatremia (113 mmol / l) were observed in the patient. After discontinuation of oxcarbazepine, the symptoms resolved and normalization of natriemia occurred [60].

Hyponatraemia has also been reported following the use of valproic acid and its derivatives. Patel et al. presented a case of hyponatremia in a patient treated with sodium valproate. Prior to initiation of treatment, the patient's sodium level was $139 \mathrm{mmol} / \mathrm{l}$ and decreased to $126 \mathrm{mmol} / \mathrm{l}$ after using sodium valproates for 2 weeks. After exclusion of other factors that might reduce the serum sodium levels, hyponatremia was associated with sodium valproate use and after its withdrawal was started, the sodium level started to normalize [61].

The number of reports of hyponatraemia due to lamotrigine use is limited, while Kılıç et al., described the case of 7.5 year-old girl after craniopharyngioma surgery, with hypopituitarism in whom symptoms of diabetes insipidus coexisted, and therefore desmopressin was used. The patient was admitted to the hospital due to vomiting and generalized tonic-clonic seizures. On the 5 th day after the inclusion of lamotrigine, the patient experienced symptoms of SIADH. The serum sodium level was $114 \mathrm{mmol} / \mathrm{l}$ and $103 \mathrm{mmol} / \mathrm{l}$ the next 6 hours. Despite the reduced dose of desmopressin and fluid restriction, the serum sodium level remained below normal. After lamotrigine was discontinued, sodium levels began to increase and after about a week normalization of sodium level occurred [62].

Similarly, Mewasingh et al., describe two cases of patients with diabetes insipidus and seizures, who, because of lamotrigine use, required reducing the desmopressin dose [63].

The occurrence of hyponatraemia with antiepileptic drugs use (normotymic) has also been a subject of review papers.

$\mathrm{Lu}$ and Wang reviewed the literature from 1966 to 2015 on hyponatremia after antiepileptic therapy, concluding that hyponatremia was most commonly caused by car- bamazepine and oxcarbazepine, but also hyponatraemia due to valproates and lamotrigine administration has been noted. Older age, high doses, low initial serum sodium and female sex, increased the risk of hyponatremia [64].

Dong et al. examined sodium concentrations in 97 patients treated with oxcarbazepine and 451 treated with carbamazepine. Hyponatremia was found in $29.9 \%$ and $13.5 \%$ of patients (severe hyponatremia occurred in $12.4 \%$ and $2.8 \%$ respectively) [65].

Young-Soo et al. reviewed literature on hyponatraemia in patients treated with oxcarbazepine who were hospitalized at Seoul National University Hospital. They confirmed that the use of daily average oxcarbazepine doses did not increase the risk of severe and symptomatic hyponatraemia. The literature analysis of the subject indicated that some of the authors pointed out the existence of a relationship between oxcarbazepine doses and hyponatraemia, while others did not share this view.

Another aspect of this work was the reported increase in the risk of hyponatraemia with concomitant use of oxcarbazepine with other drugs, including antiepileptic drugs [66].

The literature review of the subject shows that the use of mood stabilizing drugs may lead to hyponatremia, including severe hyponatremia. Carbamazepine and oxcarbazepine are among the drugs most commonly associated with hyponatremia, but it has also been reported after valproates and lamotrigine use [64]. It is therefore necessary to regularly monitor serum sodium levels when using normotinic drugs for early detection of hyponatremia [61,66].

\section{Conclusion}

Hyponatremia is an important phenomenon in the practice of a psychiatrist, and its consequence is the worsening of patient's clinical condition. While mild hyponatraemia (serum sodium level $130-135 \mathrm{mmol} / \mathrm{l}$ ) is usually asymptomatic, a drop in sodium concentration from 129 to $125 \mathrm{mmol} / \mathrm{l}$ (moderate hyponatremia) may cause weakness, nausea and vomiting. Severe hyponatremia (serum sodium level $<125 \mathrm{mmol} /$ l) causes headache, nausea, vomiting, anorexia, and orientation disorder, and convulsions, and coma may occur with a drop below $110 \mathrm{mmol} / \mathrm{l}$.

Among the causes of hyponatremia encountered in psychiatric practice, we can distinguish water intoxication associated with polydipsia, somatic comorbidity, adverse side effect of internal medicine and psychiatric drugs. The most common mechanism leading in these cases to hyponatremia is vasopressin secretion disorder (SIADH syndrome). Drug-induced hyponatremia in patients treated for mental disorders is most commonly observed with the use of antidepressants, antipsychotics, and antiepileptic drugs (used in psychiatry as normotimics). Taking into account the 
above drugs, the biggest number of literature references was for SSRIs and SNRIs, atypical neuroleptics and carbamazepine and oxcarbazepine. With regard to literature review, it is extremely important to monitor the level of natremia during pharmacotherapy with the above-mentioned drugs, especially in the early stages of treatment, although literature suggests that it may appear at every stage of treatment.
Dokonano przeglądu literatury dotyczącej hiponatremii u pacjentów leczonych $\mathrm{z}$ rozpoznaniem zaburzeń psychicznych. Pracę podzielono na dwa osobne artykuły. W pierwszym omówiono zespół nieadekwatnego wydzielania wazopresyny (SIADH) oraz zjawisko hiponatremii pojawiającej się po zastosowaniu leków psychotropowych ( leków przeciwdepresyjnych, leków przeciwpsychotycznych, leków normotymicznych), natomiast $\mathrm{w}$ drugim artykule dokonano przeglądu badań dotyczących polidypsji psychogennej.

\section{Wstęp}

Sód jest głównym kationem płynu zewnątrzkomórkowego, odpowiadającym za równowagę wodno-elektrolitową i kwasowo-zasadową w organizmie. Utrzymywanie właściwego poziomu sodu w surowicy polega na zrównoważonej podaży i wydalaniu wody, regulowanych przez ośrodek pragnienia i wydzielanie hormonu antydiuretycznego [1]. Sód wraz z potasem reguluje ciśnienie osmotyczne płynów ustrojowych oraz tworzy potencjał czynnościowy odpowiadający za przewodnictwo impulsów nerwowych, a także skurcz i rozkurcz mięśni szkieletowych i serca [2]. Ponadto umożliwia aktywny transport aminokwasów i węglowodanów do tkanek dzięki gradientowi sodowemu [3]. W warunkach fizjologicznych stężenie sodu w surowicy krwi utrzymuje się w między 135 - $145 \mathrm{mmol} / \mathrm{l}$ [4].

Hiponatremia definiowana jako zmniejszenie stężenia sodu w surowicy krwi poniżej $135 \mathrm{mmol} / \mathrm{l}$, jest najczęściej spotykanym zaburzeniem elektrolitowym $\mathrm{w}$ praktyce klinicznej [5] i może być spowodowana nadmiernym spożyciem wody pozbawionej elektrolitów przez chorych z upośledzoną czynnością wydalniczą nerek, nadmiernym wypijaniem wody [6] lub nieproporcjonalnie silniejszą utratą sodu niż wody przez nerki, przewód pokarmowy, skórę [7]. Zmniejszenie stężenia sodu w surowicy doprowadza do powstania gradientu osmotycznego pomiędzy płynem zewnątrzkomórkowym a płynem tkankowym w komórkach mózgowych, co powoduje wnikanie wody do komórek, zwiększenie objętości wewnątrzkomórkowej, a w konsekwencji prowadzi do obrzęku tkanek i objawów neurologicznych [8].

Hiponatremię w zależności od stężenia sodu w surowicy dzieli się na łagodną, umiarkowaną i ciężką [4] (Tab. 1).
Tabela 1. Podział hiponatremii w zależności od stężenia sodu w surowicy

\begin{tabular}{|c|c|}
\hline Stopień & Stężenie sodu[mmol/l] \\
\hline łagodna & $130-135$ \\
\hline umiarkowana & $125-129$ \\
\hline ciężka & $<125$ \\
\hline
\end{tabular}

Łagodna hiponatremia (stężenie sodu 130-135 mmol/l) jest zwykle bezobjawowa.

Przy spadku stężenia sodu od 129 do $125 \mathrm{mmol} / \mathrm{l}$ (hiponatremia umiarkowana) mogą wystąpić osłabienie, nudności, wymioty. W hiponatremii ciężkiej (stężenie sodu <125 mmol/l) pojawiają się bóle głowy, nudności, wymioty, brak łaknienia i zaburzenia orientacji, zaś przy spadku poniżej 110 mmol/l mogą wystąpić drgawki i śpiączka [4,5].

W zależności od czasu trwania i szybkości rozwoju wyróżnia się hiponatremię ostrą i przewlekłą (Tab. 2). Podział ten determinuje sposoby wyrównywania natremii.

Tabela 2. Definicja hiponatremii w zależności od czasu trwania

\begin{tabular}{|c|c|}
\hline Definicja & Czas trwania \\
\hline ostra & $<48 \mathrm{~h}$ \\
\hline przewlekła & $>48 \mathrm{~h}$ \\
\hline
\end{tabular}

Hiponatremię, która rozwija się w czasie krótszym niż 48 godzin definiuje się jako ostrą, zaś trwającą powyżej 48 godzin określa się jako przewlekłą [9]. U pacjentów, u których nie można określić czasu trwania hiponatremii należy przyjąć, że rozwinęła się hiponatremia przewlekła [10].

Hiponatremia ostra wiąże się ze zwiększoną śmiertelnością, co jest wynikiem szybkiego rozwoju obrzęku mózgu [11]. W przewlekłej hiponatremii w mózgu mogą się uruchamiać mechanizmy adaptacyjne, polegające na zwiększeniu wydalania elektrolitów i substancji organicznych do przestrzeni pozakomórkowej, co w konsekwencji prowadzi do utraty wody i zmniejszenia obrzęku [8].

Jony sodu są głównym osmolitem przestrzeni pozakomórkowej, a zmniejszenie ich stężenia w osoczu powoduje hipotonię płynu pozakomórkowego, stąd hiponatremia i hipoosmolalność są używane jako synonimy [12].

Hiponatremia może występować u osób wykazujących cechy odwodnienia, prawidłowego uwodnienia lub przewodnienia.

Uwzględniając wewnątrzkomórkowe zasoby wodne dzieli się hiponatremię przebiegającą z hipowolemią, hiperwolemią oraz normowolemią [6] (Tab. 3). 
Tabela 3. Podział hiponatremii w zależności od objętości płynów ustrojowych

\begin{tabular}{|c|c|c|}
\hline Rodzaj hiponatremii & \multicolumn{2}{|c|}{ Przyczyny } \\
\hline hipowolemiczna & 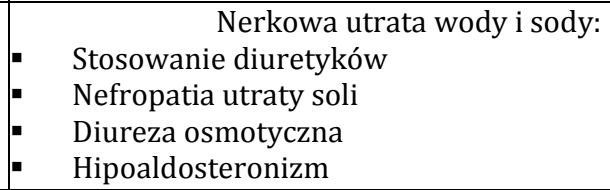 & $\begin{array}{l}\text { Pozanerkowa utrata wody i sodu: } \\
\text { Przez przewód pokarmowy(biegunki, } \\
\text { wymioty, niedrożność jelit - utrata } \\
\text { do trzeciej przestrzeni) } \\
\text { Przez skórę(oparzenia) }\end{array}$ \\
\hline normowolemiczna & $\begin{array}{l}\text { SIADH } \\
\text { Niedoczynność tarczycy } \\
\text { Niedoczynność nadnerczy } \\
\text { Polidypsja psychogenna } \\
\text { Długotrwały wysiłek fizyczny }\end{array}$ & \\
\hline hiperwolemiczna & $\begin{array}{l}\text { Choroby nerek(Przewlekła choroba nerek, ze } \\
\text { Marskość wątroby } \\
\text { Niewydolność serca }\end{array}$ & \\
\hline
\end{tabular}

Hiponatremia hipowolemiczna jest wynikiem jednoczesnej utraty wody i sodu przez skórę, przewód pokarmowy lub nerki. Może być ona powodowana przez wymioty, biegunkę, zapalenie trzustki, oparzenia skóry i błon śluzowych, stosowanie diuretyków, nefropatię utraty soli oraz chorobę Addisona [12].

Hiponatremia hiperwolemiczna może występować w niewydolności serca, marskości wątroby z wodobrzuszem oraz w chorobach nerek - zespole nerczycowym, ostrej lub przewlekłej niewydolności nerek. Wspólną cechą tego rodzaju hiponatremii jest hipoperfuzja narządowa pomimo przewodnienia organizmu. Prowadzi ona poprzez baroreceptory do zwiększonego wydzielania wazopresyny i w konsekwencji dalszej retencji wody i nasilenia hiponatremii [6].

Hiponatremia normowolemiczna występuje przede wszystkim w ciężkich przypadkach niedoczynności tarczycy oraz przedniego płata przysadki [13]. Przyczyną hiponatremii przebiegającej $\mathrm{z}$ prawidłowym uwodnieniem może być także nadmierne wydzielenie hormonu antydiuretycznego, spowodowane ektopowym wydzielaniem ADH w chorobach nowotworowych, nadmierne pobudzenie wydzielanie ADH u chorych z chorobami płuc, ośrodkowego układu nerwowego, a także wywołane lekami $[4,14]$.

Istnieją jednak dwie sytuacje, w których oznaczona hiponatremia nie jest równoznaczna z hipoosmolalnością. Są to hiponatremia niehipotoniczna (izotoniczna lub hipertoniczna) oraz pseudohiponatremia [12]. Ta pierwsza jest spowodowana przemieszczaniem wody z przestrzeni śródkomórkowej do pozakomórkowej na skutek zwiększonego stężenia w osoczu substancji osmotycznie czynnych (takich jak glukoza, mannitol, środki kontrastowe stosowane w radiologii)[13], natomiast pseudohiponatremia występuje przy hiperlipidemii, hiperglikemii, hiperurykemii lub hiperproteinemii, które powodują względne zmniejszenie się fazy wodnej osocza. Każda mierzona objętość osocza zawiera w tym przypadku mniej jonów sodowych co skutkuje fałszywymi wartościami stężenia sodu w surowicy $[12,15]$.

Wśród przyczyn hiponatremii u pacjentów leczonych w oddziałach psychiatrycznych najczęściej wyróżnia się:

-zatrucie wodne związane z polidypsją

-współwystępowanie chorób somatycznych

-działanie niepożądane leków internistycznych i psychiatrycznych [16].

Najczęstszym mechanizmem doprowadzającym w tych przypadkach do hiponatremii jest zaburzenie wydzielania wazopresyny (zespół SIADH) [16].

\section{Cel i metoda}

W pierwszym artykule dokonano przeglądu literatury, dotyczącej zespołu nieadekwatnego wydzielania wazopresyny (SIADH) oraz zjawiska hiponatremii pojawiającej się po zastosowaniu leków psychotropowych, używając baz danych Google Scholar i Pub Med i dzieląc go na dwa podrozdziały:

1. Zespół nieadekwatnego wydzielania wazopresyny (SIADH)

2. Hiponatremia a leki psychotropowe (leki przeciwdepresyjne, leki przeciwpsychotyczne, leki normotymiczne)

\section{Zespół nieadekwatnego wydzielania wazopresyny (SIADH)}

SIADH to zespół objawów, po raz pierwszy opisany w 1967 przez Schwartza i Barttera w The American Journal of Medicine [17], który powstaje przy nadmiernym uwalnianiu hormonu antydiuretycznego (ADH - antidiuretic hormone), zwanego też wazopresyną, co powoduje u pacjentów rozwój hiponatermii normowolemicznej [18].

\section{Patogeneza}

Istnieją cztery podstawowe typy SIADH, w zależności od modelu uwalniania wazopresyny: 
1) typ A, występujący najczęściej (40\% przypadków), opisywany był zwykle u pacjentów chorujących na raka drobnokomórkowego płuc, wydzielającego ektopowo wazopresynę. ADH uwalniane jest zatem w sposób całkowicie nieregulowany przez osmolalność osocza. Pomimo spadku osmolalności osocza, sekrecja ADH pozostaje niezahamowana i może dojść do rozwoju ciężkiej hiponatremii, jeśli pacjent kontynuuje przyjmowanie płynów [19]. W tym typie SIADH progowa wartość osmolalności osocza, powodująca zahamowanie ośrodka pragnienia, jest niższa niż zwykle, co powoduje, że hiponatremia u pacjenta nie zostanie wyrównana przez samoograniczenie przyjmowania płynów [20].

2) typ B, w którym zachowana jest linearna zależność między osomolalnością osocza a stężeniem wydzielanej wazopresyny, ale progowa wartość osmolalności osocza, która powoduje zahamowanie wydzielania wazopresyny, jest niższa niż fizjologicznie. Dochodzi zatem do obniżenia poziomu natremii, która osiąga stabilne wartości, zwykle między 125 a 135 mmol/l [19].

3) typ C, stanowiący rzadką odmianę SIADH, w którym przy osmolalności osocza powyżej $284 \mathrm{mOsm} / \mathrm{kg}$ linearna zależność między osmolalnością osocza a stężeniem wydzielanej wazopresyny jest zachowana. Jednakże, gdy osmolalność osocza spada poniżej $284 \mathrm{mOsm} / \mathrm{kg}$, zmniejszona osmolalność osocza nie powoduje supresji wydzielania ADH. Dzieje się tak prawdopodobnie z powodu zaburzeń w zakresie funkcji hamujących dróg neuronalnych podwzgórza. Niskie wartości wazopresyny są stale wykrywalne w osoczu [19].

4) typ D, występujący najrzadziej wariant SIADH, w którym spełnione są formalne kryteria rozpoznania tego zespołu, ale stężenie ADH w surowicy jest niewykrywalne. Może to być spowodowane wytwarzaniem innych czynników antydiuretycznych przez komórki nowotworowe, bądź też mutacją receptorów V2 dla wazopresyny w kanalikach nerkowych, która powoduje ich stałą aktywację [19].

\section{Kryteria diagnostyczne}

Kryteria diagnostyczne SIADH opisane po raz pierwszy przez Schwartza i Barttera, uległy na przestrzeni lat zmianie $\mathrm{i}$ swoistej ewolucji, $\mathrm{w}$ związku $\mathrm{z}$ nowymi odkryciami i pełniejszym zrozumieniem przyczyn występowania tego zespołu. Aktualne kryteria European Renal Association - European Dialysis and Transplant Association (ERA-EDTA), stosowane w Europie, przedstawia tabela 4 [5]. Do rozpoznania zespołu konieczne jest spełnienie wszystkich kryteriów głównych. Jeśli nie wszystkie kryteria główne są spełnione, obecność kryteriów dodatkowych zwiększa prawdopodobieństwo występowania zespołu SIADH. Niegdyś wśród kryteriów dodatkowych wymieniano podwyższone stężenie wazopresyny we krwi, jednakże obecnie nie jest to zalecane, głównie ze względu na techniczne trudności w jej oznaczaniu oraz w interpretacji wyników, z powodu zmiennej zależności pomiędzy osoczowym stężeniem ADH a utratą wolnej wody i elektrolitów [5].

Tabela 4. Kryteria rozpoznania SIADH (Za: Spasovski, G. et al.) [5]

\begin{tabular}{|l|}
\hline Kryteria główne: \\
efektywna osmolalność osocza $<275$ mOsm/kg \\
osmolalność moczu $>100 \mathrm{mOsm} / \mathrm{kg}$ \\
euwolemia w ocenie klinicznej \\
stężenie Na w moczu > 30 mmol/l przy prawidłowym \\
spożyciu sodu I wody \\
nieobecność niewydolności nadnerczy, tarczycy, \\
przysadki lub nerek \\
niestosowanie diuretyków tiazydowych w ostatnim \\
czasie \\
\hline Kryteria dodatkowe: \\
stężenie kwasu moczowego w surowicy < 0,24 mmol/l \\
(<4 mg/dl) \\
stężenie mocznika w surowicy < 3,6 mmol/l (<21,6 \\
mg/dl) \\
niepowodzenie w wyrównaniu hiponatremii za pomocą \\
wlewów dożylnych 0,9\% NaCl \\
frakcyjne wydzielanie sodu $>0,5 \%$ \\
frakcyjne wydalanie mocznika $>55 \%$ \\
frakcyjne wydalanie kwasu moczowego $>12 \%$ \\
korekcja hiponatremii poprzez ograniczenie doustnej \\
podaży płynów
\end{tabular}

Należy podkreślić, że SIADH jest rozpoznaniem, które stawiane jest przez wykluczenie. Oprócz niewydolności nadnerczy, tarczycy, przysadki i nerek, należy wykluczyć również przewlekłą hipowolemię oraz hiponatremię rzekomą [5].

Obraz kliniczny SIADH stanowią typowe objawy spowodowane hiponatremią. Możemy wśród nich wymienić ból głowy, nudności, wymioty, skurcze mięśniowe, niepokój, głęboką senność, splątanie, osłabienie odruchów. Następstwem gwałtownie rozwijającej się hiponatremii może być niewydolność krążeniowo-oddechowa, wgłobienie pnia mózgu oraz śmierć [21].

\section{Przyczyny}

Przyczyny mogące wywołać zespół nieadekwatnego wydzielania wazopresyny są bardzo zróżnicowane (Tab. 5). Według różnych źródeł najczęstszą przyczyną SIADH są nowotwory, choroby ośrodkowego układu nerwowego lub leki [22, 23, 24].

Pierwszy opis SIADH pochodzący z 1967 roku dotyczył pacjenta chorującego na raka płuc [17]. Nowotwór ten może wywołać zespół nieadekwatnego wydzielania wazopresyny aż w 15\% przypadków [22]. 
Tabela 5. Przyczyny SIADH (za: Cuesta et al.[19] i Verbalis et al.[12])

\begin{tabular}{|l|}
\hline Nowotwory: \\
płuc/śródpiersia (rak płuca, międzybłoniak opłucnej, \\
grasiczak) \\
inne (rak dwunastnicy, rak trzustki, rak prostaty, rak \\
trzonu macicy, rak jamy nosowo-gardłowej, białaczka, \\
chłoniaki, mięsaki) \\
\hline Patologie OUN \\
masywne uszkodzenia (guzy, ropnie, krwiaki) \\
choroby zapalne (zapalenie mózgu, zapalenie opon mó- \\
zgowo-rdzeniowych, toczeń, ostra porfiria przerywana) \\
Choroby neurodegeneracyjne i demielinizacyjne (choro- \\
ba Guillan-Barre, stwardnienie rozsiane) \\
Różne (krwotok podpajęczynówkowy, ostra psychoza, \\
delirium tremens, wodogłowie, zapalenie naczyń, za- \\
krzepica zatoki jamistej) \\
\hline Leki \\
stymulacja sekrecji ADH (nikotyna, pochodne fenotiazy- \\
ny, trójcykliczne leki przeciwdepresyjne) \\
wpływ na nerki lub potencjalizacja antydiuretycznego \\
działania ADH (desmopresyna, oksytocyna, inhibitory \\
syntezy prostaglandyn) \\
działanie wieloczynnikowe lub nieznane (inhibitory \\
konwertazy angiotensyny, karbamazepina, klofibrat, klo- \\
zapina, cyklofosfamid, 3,4-metylenodioksymetamfetamina \\
[“Ecstasy”], omeprazol, inhibitory wychwytu zwrotnego sero- \\
toniny, winkrystyna) \\
\hline Choroby płuc \\
infekcje (gruźlica, zapalenie płuc, aspergilloza, ropniak \\
opłucnej, rozstrzenie oskrzeli) \\
inne (ostra niewydolność oddechowa, przewlekła obtu- \\
racyjna choroba płuc, mechaniczna wentylacja dodatnim \\
ciśnieniem) \\
\hline Inne \\
zespół nabytego niedoboru odporności \\
przedłużony wytężony wysiłek fizyczny (maraton, tria- \\
tlon, itd) \\
olbrzymiokomórkowe zapalenie naczyń \\
idiopatyczne \\
\end{tabular}

Przebieg SIADH różni się $\mathrm{w}$ zależności od wywołującej go przyczyny. SIADH spowodowany chorobami ośrodkowego układu nerwowego często ma cięższy przebieg $\mathrm{W}$ porównaniu $\mathrm{z}$ zespołem nieadekwatnej diurezy wywołanym innymi patologiami. Etiologia jest też ważnym czynnikiem mającym wpływ na prognozę szybkiego wyrównania natremii. W zespole SIADH, wywołanym potencjalnie odwracalnymi przyczynami, takimi jak infekcje lub przyjmowane leki, powrót do prawidłowej natremii jest łatwiej osiągalny, niż w zespole nieadekwatnego wydzielania wazopresyny mającym etiologię nowotworową [24].

\section{Leczenie SIADH}

Zespół nieadekwatnego wydzielania wazopresyny powinien być leczony przyczynowo, jeżeli jest to możliwe. W przypadku pacjentów leczonych psychiatrycznie, przyczynowym leczeniem SIADH będzie najczęściej odstawienie leku, który wywołał zaburzenia elektrolitowe [22].
Wg wielu doniesień $[22,25]$, często jest to wystarczająca metoda leczenia (w przypadku leków z grupy SSRI najczęściej po około 2 tygodniach od odstawienia leku natremia ulega wyrównaniu) [25].

Przy przewlekłej hiponatremii wywołanej SIADH, bez ciężkich lub umiarkowanych objawów, jako leczenie pierwszego rzutu rekomenduje się ograniczenie przyjmowania płynów [5]. Objętość przyjmowanych płynów powinna być mniejsza o $500 \mathrm{ml}$ od objętości moczu wydalanego $\mathrm{w}$ ciągu doby przez pacjenta. Wielu pacjentów na tę metodę leczenia reaguje powoli i potrzeba kilku dni, by osiągnąć normalizację stężenia sodu w osoczu[22].

Leczeniem drugiego rzutu jest zwiększenie podaży sodu, za pomocą mocznika stosowanego doustnie w dawce 0,25- 0,5 g/kg m.c./d. bądź też zastosowanie chlorku sodu w formie doustnej w skojarzeniu $\mathrm{z}$ diuretykiem pętlowym w małej dawce [5].

Zalecenia dotyczące stosowania demeklocykliny w SIADH są rozbieżne. Tylko w niektórych krajach jest ona zarejestrowana w tym wskazaniu [22], natomiast Europejskie Towarzystwa nie zalecają stosowania jej w leczeniu zespołu nieadekwatnej diurezy, podobnie jest z litem [5]. Również doniesienia na temat stosowania waptanów, czyli antagonistów receptora dla wazopresyny, są różne. Amerykańscy badacze opublikowali w Clinical Journal of Medicine badanie, $\mathrm{z}$ kórego wynika, że zastosowanie waptanów w leczeniu SIADH może skracać czas hospitalizacji pacjentów [26], natomiast według wspólnego stanowiska Europejskiego Towarzystwa Intensywnej Opieki Medycznej, Europejskiego Towarzystwa Endokrynologicznego oraz Europejskiego Stowarzyszenia Nefrologicznego, antagoniści receptorów wazopresyny, mimo że powodują zwiększenie poziomu sodu w osoczu, nie powinny być obecnie zalecane w leczeniu SIADH. Uznano, że stosunek korzyści do ryzyka podczas stosowania tych substancji wypada negatywnie. Najważniejszym czynnikiem, który ogranicza bezpieczeństwo stosowania waptanów, jest ryzyko zbyt szybkiego wyrównania natremii podczas ich stosowania i związane z tym niebezpieczeństwo rozwoju zespołu demielinizacyjnego [5].

Należy podkreślić, że podczas leczenia zespołu SIADH zawsze powinno stosować się do ogólnych zaleceń leczenia hiponatremii hipotonicznej, które przedstawiliśmy w tabeli 6 [5].

2. Hiponatremia a leki psychotropowe (leki przeciwdepresyjne, leki przeciwpsychotyczne, leki normotymiczne)

\section{SIADH a leki przeciwdepresyjne}

Istnieje wiele danych na temat występowania hiponatremii po zastosowaniu selektywnych inhibitorów wychwytu zwrotnego serotoniny (SSRI) [27]. Wiele badań 
wymienić występowanie hiponatremii u pacjenta w przeszłości, masę ciała < $60 \mathrm{~kg}$, obecność objawów psychotycznych [31], płeć żeńską [25] oraz stosowanie leków przeciwdepresyjnych w skojarzeniu z diuretykami, inhibitorami konwertazy angiotensyny (ACEI) lub inhibitorami pompy protonowej (IPP) [34].

$\mathrm{W}$ większości doniesień hiponatremia rozwija się na początku stosowania leków, w przypadku SSRI pojawia się najczęściej między 3 a 120 dniem od włączenia leczenia, średnio w 13 dniu. Największe ryzyko występuje w pierwszym miesiącu leczenia [38], w przypadku citalopramu średnio między 6 a 20 dniem stosowania [39]. Fabian i wsp. zbadali występowanie hiponatremii u starszych pacjentów po zastosowaniu paroksetyny. Badana grupa liczyła 75 osób w wieku od 63 do 90 lat. Poziom natremii monitorowano przed rozpoczęciem terapii paroksetyną, co tydzień przez pierwsze 4 tygodnie leczenia, a następnie po 1,2,3,4, 6 i 12 tygodniach od rozpoczęcia terapii. Hiponatremia rozwinęła się u 9 spośród 75 pacjentów (12\%). Średni czas od rozpoczęcia leczenia do rozwinięcia się zaburzeń elektrolitowych wyniósł 9.3 +/- 4.7 dni [40]. Opisano jednak przypadek, gdy SIADH rozwinął się dopiero po 16 miesiącach od włączenia paroksetyny [41]. Analiza wybranych przypadków pozwala stwierdzić, że po zastosowaniu leków przeciwdepresyjnych hiponatremia może rozwinąć się nagle, korzystne jest zatem monitorowanie poziomu elektrolitów na początku leczenia [38, 39, 41].

Istnieją jednakże badania, których wyniki sugerują, że leki z grupy SSRI nie są istotnie związane z rozwojem hiponatremii u osób z grupy ryzyka. Noohi i wsp. przeprowadzili retrospektywne badanie 239 hospitalizowanych pacjentów. Podzielono ich na trzy grupy: pacjentów przyjmujących SSRI, chorych przyjmujących inne leki przeciwdepresyjne oraz tych, którzy nie otrzymywali żadnego leczenia przeciwdepresyjnego. Największy spadek osoczowego stężenia sodu nie różnił się w sposób statystycznie istotny $\mathrm{w}$ badanych grupach (SSRI - 3,31 mmol/l, inne LPD - $3.41 \mathrm{mmol} / \mathrm{l}$, bez leczenia przeciwdepresyjnego - $3.13 \mathrm{mmol} / \mathrm{l})$. Również częstość występowania hiponatremii nie różniła się istotnie w badanych grupach [42].

\section{SIADH a leki przeciwpsychotyczne}

Ocena ryzyka hiponatremii po zastosowaniu neuroleptyków klasycznych i atypowych opiera się aktualnie na wielu opisach kazuistycznych, nie przeprowadzono systematycznych badań w tym obszarze [43].

W 1997 roku Whitten i Ruehter opisali przypadek 48-letniego mężczyzny, bez zaburzeń endokrynologicznych i bez choroby nerek w wywiadzie, nie leczonego diuretykami, który siedem dni po włączeniu risperidonu rozwinął objawową hiponatremię $\mathrm{z}$ drgawkami, rabdomiolizą oraz zaburzeniami oddychania. Za potencjalny mechanizm pojawienia się hiponatremii uznano zespół SIADH w wyniku zastosowania risperidonu [44].

Z kolei Atalay i wsp. opisali przypadek 76-letniego mężczyzny, leczonego escitalopramem i kwetiapiną, a następnie citalopramem i kwetiapiną, u którego w wyniku zastosowanego leczenia pojawiła się hiponatremia. Po odstawieniu leków z grupy SSRI hiponatremia utrzymywała się, natomiast ustąpiła dopiero kilka dni po odstawieniu kwetiapiny, stąd za przyczynę problemu uznano ten atypowy neuroleptyk [45].

Hiponatremia jako niepożądane działanie polekowe była również opisywana po zastosowaniu olanzapiny. Bakhla i wsp. opisali przypadek 63-letniego mężczyzny z rozpoznaniem ciężkiego epizodu depresji z objawami psychotycznymi w przebiegu zaburzeń depresyjnych nawracających, leczonego escitalopramem oraz olanzapiną. Leczenie za pomocą leku przeciwdepresyjnego rozpoczęto dwa lata wcześniej i nie obserwowano w tym czasie objawów ubocznych, natomiast po włączeniu olanzapiny u pacjenta pojawiła się objawowa hiponatremia, stąd za jej przyczynę, również i w tym przypadku, uznano atypowy neuroleptyk [46]. Z kolei Dudeja i wsp. opisali przypadek 48-letniej kobiety leczonej przez dwa lata olanzapiną w dawce 20 mg na dobę, u której rozwinęła się hiponatremia skutkująca zatrzymaniem oddechu. Nie wykryto innych potencjalnych przyczyn pojawienia się hiponatremii, a po odstawieniu olanzapiny obserwowano normalizację poziomu sodu [47].

Hiponatremia polekowa była również obserwowana po zastosowaniu klasycznych leków przeciwpsychotycznych [48]: haloperidolu [49] oraz tiorydazyny [50].

Zjawisko występowania hiponatremii polekowej było również tematem prac przeglądowych i retrospektywnych badań populacyjnych.

Correll i wsp. dokonali przeglądu literatury w celu oszacowania występowania działań niepożądanych po zastosowaniu leków psychotropowych w wybranych zaburzeniach psychicznych, potwierdzając doniesienia o pojawieniu się hiponatremii w przebiegu leczenia przeciwpsychotycznego [51].

Z kolei Meulendijks i wsp. dokonali systematycznego przeglądu literatury dotyczącej występowania hiponatremii po zastosowaniu leków przeciwpsychotycznych, ze szczególnym uwzględnieniem charakterystyk pacjentów, dawki neuroleptyku, zjawiska polidypsji oraz zespołu SIADH [52]. Autorzy przeszukali bazy MEDLINE oraz EMBASE w okresie od stycznia 1966r.do 11 kwietnia 2009r., używając kryteriów włączenia tj. wystąpienie hiponatremii (natremia poniżej $136 \mathrm{mmol} / \mathrm{l}$ ) po rozpoczęciu leczenia neuroleptykiem oraz zaistnienie związku pomiędzy stosowaniem neuroleptyku a hiponatremią według definicji WHO. Analiza 4 badań oraz 91 opisów przypadków zgodnych z kryteriami włączenia wykazała, 
iż zarówno neuroleptyki klasyczne, jak i atypowe mogą wiązać się z pojawieniem polekowej hiponatremii [52].

W pracy z 2010r. Mannesse i wsp. przeanalizowali związki pomiędzy stosowaniem neuroleptyków atypowych a hiponatremią. Do sierpnia 2008r. w bazie VigiBase zarejestrowano ponad 3 miliony (3 881 518) działań niepożądanych po lekach, z czego 912 raportów dotyczyło hiponatremii po zastosowaniu neuroleptyków. Autorzy tej analizy zaobserwowali, iż olanzapina oraz risperidon (a także inne atypowe neuroleptyki) były związane częściej z pojawieniem się hiponatremii niż innych działań niepożądanych [53].

Z kolei Gandhi i wsp. przeanalizowali bazy zawierające dane pochodzące $\mathrm{z}$ systemów opieki zdrowotnej w celu przeprowadzenia retrospektywnego populacyjnego badania kohortowego starszych pacjentów powyżej 65 rż. z Ontario w Kanadzie. Wyniki tej analizy wskazują, iż stosowanie atypowego neuroleptyku wiązało się ze zwiększonym 30-dniowym ryzykiem hospitalizacji z powodu hiponatremii w porównaniu do sytuacji nie stosowania neuroleptyku $(0,15 \%$ vs. $0,09 \%)$; względne ryzyko 1,62 , całkowity wzrost ryzyka o 0,06\% [43].

Również Shepshelovich i wsp. analizowali zjawisko hiponatremii u pacjentów przyjmujących różne grupy leków: leki przeciwdepresyjne, przeciwpsychotyczne, przeciwpadaczkowe, przeciwbólowe, cytostatyki oraz inne leki potencjalnie związane z wystąpieniem hiponatremii. Autorzy przebadali 198 pacjentów z rozpoznaniem SIADH, z czego 73,7\% przypadków było związane z etiologią polekową. W celu zróżnicowania przyczyny SIADH zastosowano skalę Naranjo (1981), która ocenia stopień prawdopodobieństwa wystąpienia hiponatremii indukowanej zastosowaną farmakoterapią. $\mathrm{W}$ tym badaniu lekami najczęściej powiązanymi z wystąpieniem SIADH były leki przeciwdepresyjne, zaś wśród neuroleptyków (22 przypadki SIADH) dominował risperidon [54].

Analizując problem hiponatremii u pacjentów leczonych $\mathrm{z}$ rozpoznaniem zaburzeń psychotycznych należy zróżnicować dwie kwestie: hiponatremię indukowaną leczeniem przeciwpsychotycznym oraz hiponatremię indukowaną samą psychozą, do czego odnoszą się Atsariyasing i Goldman [55]. Autorzy przeszukali bazę MEDLINE od 1960 roku do września 2012 roku, uwzględniając prace analizowane wcześniej przez Meulendijks i wsp., używając słów- kluczy: hiponatremia, SIADH, leki przeciwpsychotyczne, język angielski. Wstępnie do dalszych analiz zakwalifikowano 186 artykułów, z czego po stopniowych selekcjach do badania weszło ostatecznie 39 prac (54 pacjentów leczonych w warunkach szpitalnych). Oceny stopnia prawdopodobieństwa wystąpienia polekowej hiponatremii dokonano za pomocą skali Naranjo (1981). Wyniki tego badania wskazują, iż ocena zagęszczenia moczu może być pomocna dla zróżnicowania hiponatremii polekowej i hiponatremii indukowanej psychozą.

\section{SIADH a leki normotymiczne}

Przyczyną hiponatremii polekowej mogą być również leki przeciwpadaczkowe, stosowane w psychiatrii jako leki normotymiczne [56,57].

Kuz i Manssourian opisali przypadek 44-letniej kobiety leczonej karbamazepiną, u której po przyjęciu dwukrotnej wieczornej dawki leku (2x600 mg) wystąpiła ciężka hiponatremia. U pacjentki $\mathrm{w}$ chwili przyjęcia do szpitala stężenie sodu w surowicy wynosiło $122 \mathrm{mmol} / \mathrm{l}$, a po zastosowaniu $0,9 \%$ wlewu $\mathrm{NaCl}$ oraz odstawieniu karbamazepiny, stężenie sodu w surowicy wynosiło 136 mmol/l po 24 godzinach. Pół roku wcześniej u tej samej pacjentki również wystąpiła hiponatremia po zażyciu dużej dawki karbamazepiny [58].

Przypadek jatrogennej, ciężkiej hiponatremii u pacjenta po zastosowaniu karbamazepiny opisali także Krysiak i Okopień. 59- letni mężczyzna z neuralgią nerwu trójdzielnego był leczony karbamazepiną, początkowo w dawce $200 \mathrm{mg} /$ dobę, a następnie zwiększano ją do 600 mg/dobę w 2 dawkach podzielonych. Po 2 tygodniach wystąpiły u pacjenta objawy neurologiczne, został przyjęty do szpitala z podejrzeniem udaru mózgu. Badania laboratoryjne wykazały stężenie sodu w surowicy na poziomie 112 mmol/l. Obraz kliniczny wskazywał na zespół SIADH. U pacjenta zaprzestano stosowania karbamazepiny, wyrównano natremię, a w badaniach kontrolnych wykonywanych w okresie roku od wypisu nie stwierdzono zaburzeń elektrolitowych [59].

Z kolei Kumar i Gopalakrishnan opisali przypadki hiponatremii występującej po stosowaniu okskarbazepiny. Pierwsza sytuacja miała miejsce u 57-letniego mężczyzny, który nie przyjmował innych leków oraz nie był obciążony somatycznie. Po około 3 tygodniach od wprowadzenia do leczenia okskarbazepiny u pacjenta wystąpiły wymioty, zmęczenie, zmniejszenie apetytu, trudności w oddawaniu moczu. $\mathrm{W}$ badaniach laboratoryjnych poziom sodu wynosił $115 \mathrm{mmol} / \mathrm{l}$, zaś po odstawieniu okskarbazepiny i podaniu roztworu soli fizjologicznej, poziom sodu po 3 dniach wrócił do normy. Drugi opis dotyczył 33- letniej kobiety, która również przyjmowała okskarbazepinę w terapii choroby afektywnej dwubiegunowej. Po tygodniu od rozpoczęcia stosowania leku u pacjentki wystąpiły objawy mogące wskazywać na hiponatremię (stężenie sodu wynosiło $113 \mathrm{mmol} / \mathrm{l}$ ). Po odstawieniu okskarbazepiny objawy ustąpiły i doszło do normalizacji natremii [60].

Opisywano również przypadki hiponatremii po stosowaniu kwasu walproinowego i jego pochodnych. Patel i wsp. przedstawili przypadek hiponatremii u pacjenta, w leczeniu którego stosowano walproinian sodu. Przed 
rozpoczęciem leczenia poziom sodu u pacjenta wynosił $139 \mathrm{mmol} / \mathrm{l}$, zaś po 2 tygodniach stosowania walproinianów obniżył się do poziomu $126 \mathrm{mmol} / \mathrm{l}$. Po wykluczeniu innych czynników mogących obniżać poziom sodu w surowicy, powiązano hiponatremię ze stosowaniem walproinianu i rozpoczęto jego odstawianie, co w rezultacie doprowadziło do wyrównania zaburzeń elektrolitowych [61].

Liczba doniesień o występowaniu hiponatremii w wyniku stosowania lamotryginy jest ograniczona, natomiast Kılıç i wsp. opisali przypadek 7,5 letniej dziewczynki po operacji czaszkogardlaka, $\mathrm{z}$ chorobą Glińskiego-Simmondsa, u której współwystępowały objawy moczówki prostej, w związku z czym stosowano desmopresynę. Pacjentka została przyjęta do szpitala z powodu wymiotów i uogólnionych drgawek tonicznoklonicznych. W 5. dobie od włączenia lamotryginy u pacjentki wystąpiły objawy zespołu SIADH. Poziom sodu w surowicy wynosił $114 \mathrm{mmol} / \mathrm{l} \mathrm{i} 103 \mathrm{mmol} / \mathrm{l}$ po następnych 6 godzinach. Pomimo zmniejszenia dawki desmopresyny i restrykcji płynów stężenie sodu utrzymywało się poniżej normy. Po odstawieniu lamotryginy stężenie sodu zaczęło wzrastać i po około tygodniu nastąpiła normalizacja stężenia sodu [62].

Podobnie, Mewasingh i wsp., opisali przypadki dwóch pacjentów z moczówką prostą i napadami padaczkowymi, którzy w wyniku stosowania lamotryginy wymagali zmniejszenia dawek desmopresyny [63].

Zjawisko występowania hiponatremii po zastosowaniu leków przeciwpadaczkowych (normotymicznych) było również tematem prac przeglądowych.

Lu i Wang dokonali przeglądu literatury od 1966 do 2015 roku, dotyczącej zjawiska hiponatremii po zastosowaniu leków przeciwpadaczkowych, dochodząc do wniosku, iż hiponatremia najczęściej była wywoływana przez karbamazepinę i okskarbazepinę, ale notowano również przypadki hiponatremii w wyniku stosowania walproinianów i lamotryginy. Starszy wiek, wysokie dawki, niskie początkowe stężenie sodu w surowicy oraz płeć żeńska zwiększały ryzyko hiponatremii [64].

Z kolei Dong i wsp. badali stężenie sodu u 97 pacjentów leczonych okskarbazepiną i 451 leczonych karbamazepiną. Hiponatremię stwierdzono odpowiednio u 29,9\% i 13,5\% pacjentów (ciężka hiponatremia wystąpiła odpowiednio u 12,4 \% i 2,8\% )[65].

Young-Soo i wsp. dokonali przeglądu literatury pod kątem wystąpienia hiponatremii u pacjentów leczonych okskarbazepiną, którzy byli hospitalizowani w Seoul National University Hospital, stwierdzając, że stosowanie średnich dawek dziennych okskarbazepiny nie zwiększało ryzyka ciężkiej i objawowej hiponatremii. Analiza literatury przedmiotu wskazywała ponadto, iż część autorów zwracała uwagę na istnienie związku pomiędzy dawkami okskarbazepiny a występowaniem hiponatremii, zaś inni badacze nie podzielali tego poglądu.

Innym aspektem tej pracy był opisywany wzrost ryzyka wystąpienia hiponatremii przy jednoczesnym stosowaniu okskarbazepiny $\mathrm{z}$ innymi lekami, w tym przeciwpadaczkowymi [66].

Z przeglądu literatury przedmiotu wynika, iż stosowanie leków stabilizujących nastrój może prowadzić do wystąpienia hiponatremii, w tym hiponatremii ciężkiej. Karbamazepina i okskarbazepina są w tej grupie lekami, które najczęściej przyczyniają się do wystąpienia hiponatremii, ale odnotowywano ją także po walproinianach i lamotryginie [64]. Konieczne jest zatem regularne monitorowanie stężenia sodu podczas stosowania leków normotymicznych, w celu wczesnego wykrycia hiponatremii $[61,66]$.

\section{Podsumowanie}

Hiponatremia jest zjawiskiem istotnym w praktyce lekarza psychiatry, a jego konsekwencją jest pogorszenie stanu klinicznego pacjenta. O ile łagodna hiponatremia (stężenie sodu 130-135 mmol/l) jest zwykle bezobjawowa, to już przy spadku stężenia sodu od 129 do $125 \mathrm{mmol} / \mathrm{l}$ (hiponatremia umiarkowana) mogą wystąpić osłabienie, nudności, wymioty. W hiponatremii ciężkiej (stężenie sodu <125 mmol/l) pojawiają się bóle głowy, nudności, wymioty, brak łaknienia i zaburzenia orientacji, zaś przy spadku poniżej $110 \mathrm{mmol} / \mathrm{l}$ mogą wystąpić drgawki i śpiączka.

Wśród przyczyn hiponatremii spotykanej w praktyce psychiatrycznej możemy wyróżnić zatrucie wodne związane z polidypsją, współwystępowanie chorób somatycznych, działanie niepożądane leków internistycznych i psychiatrycznych. Najczęstszym mechanizmem doprowadzającym $w$ tych przypadkach do hiponatremii jest zaburzenie wydzielania wazopresyny (zespół SIADH). Zjawisko hiponatremii polekowej u pacjentów leczonych $\mathrm{z}$ rozpoznaniem zaburzeń psychicznych jest najczęściej obserwowane po zastosowaniu leków przeciwdepresyjnych, leków przeciwpsychotycznych oraz leków przeciwpara-czkowanych (stosowanych w psychiatrii jako leki normotymiczne). Uwzględniając powyższe grupy leków, najwięcej danych z literatury odnosiło się odpowiednio do leków z grupy SSRI i SNRI, neuroleptyków atypowych oraz karbamazepiny i okskarbazepiny. W kontekście dokonanego przeglądu literatury niezwykle ważnym wydaje się być kontrola poziomu natremii podczas farmakoterapii wyżej wymienionymi lekami, szczególnie w początkowym okresie leczenia, chociaż dane z literatury sugerują, iż może ona pojawić się na każdym etapie leczenia.

\section{Conflict of interest}

The authors have declared no conflict of interest. 


\section{References}

1. Kovesdy C.P., Significance of hypo- and hypernatremia in chronic kidney disease, Nephrol Dial Transplant 2012, 27 (3): 891-898.

2. Emsley J., Nature's Building Blocks: An A-Z Guide to the Elements. Wyd. Oxford University Press 2003: 398.

3. Kuriyan J., Konforti B., Wemmer D., The Molecules of Life. Wyd. Garland Science 2013: 485.

4. Reynolds R.M., Padfield P.L., Seckl J.R., Disorders of sodium balance. BMJ. 2006 Mar 25; 332(7543): 702-705.

5. Spasovski G., Vanholder R., Allolio B., Annane D., Ball S., Bichet D., Decaux G., Fenske W., Hoorn EJ., Ichai C., Joannidis M., Soupart A., Zietse R., Haller M., van der Veer S., Van Biesen W., Nagler E., Clinical practice guideline on diagnosis and treatment of hyponatraemia, Intensive Care Med. 2014, 40: 320-331.

6. Sahay M., Sahay R., Hyponatremia: A practical approach, Indian J Endocrinol Metab. 2014 Nov-Dec, 18(6): 760-771.

7. Ciechanowski K., Hipo- i hipernatremia- przyczyny i zasady terapii, Forum Nefrologiczne 2011. Tom 4, nr 4, 362-366 Copyright (C) 2011 Via Medica ISSN 1899-3338.

8. Lum G., Severe Hyponatremia in a Schizophrenic Patient, Clinical Chemistry 2013, 59:6: 887-891.

9. Singh P., Singh A., Chawla J., Singh A., Kaur S., Singla M., Profound Hyponatremia: Prevalence, Underlying Disorders and Outcome in Tertiary Care Hospital, British Journal of Medicine \& Medical Research 2016, 14(12): 1-6.

10. Freda B.J, Nurko S., Hyponatremia and hypernatremia, Carey WD, Gordon S, eds. Cleveland Clinic: Currrent Clinical Medicine. 2 nd edition. Philadelphia, PA: Elvesier Saunders 2010: 818-823.

11. Maxwell A.P.,Diagnosis and management of hyponatraemia: AGREEing the guidelines, Maxwell BMC Medicine 2015: 13:31.

12. Verbalis J.G., Goldsmith S.R., Greenberg A., Korzelius C., Schrier R.W., Sterns R.H., Thompson C.J., Diagnosis, evaluation, and treatment of hyponatremia: Expert Panel Recommendations, Am J Med. 2013 Oct, 126(10 Suppl 1):S1-42.

13. Schrier R.W., Bansal S., Diagnosis and management of hyponatremia in acute illness, Curr Opin Crit Care. 2008 Dec, 14(6): 627-634.

14. Pillai B.P., Unnikrishnan A.G., Pavithran P.V., Syndrome of inappropriate antidiuretic hormone secretion: Revisiting a classical endocrine disorder, Indian J Endocrinol Metab. 2011 Sep, 15(Suppl3): 208-215.

15. Nguyen M.K, Ornekian V., Butch A.W., Kurtz I., A new method for determining plasma water content: application in pseudohyponatremia, American Journal of Physiology - Renal Physiology 2007, 292(5):1652-1656.

16. Załuska M.: Diagnoza i terapia hiponatremii u pacjenta z zaburzeniami psychicznymi. Farmakoter. Psych. Neurol. 2005, 2: 155-166.

17. Bartter F, Schwartz W. The syndrome of inappriopriate secretion of antidiuretic hormone. The American Journal of Medicine (1967)

18. Crowley RK, Thompson Cj. Syndrome of inappriopriate diuresis. Expert Rev Endocrinol Metabol (2006) 1:537-47

19. Cuesta M, Thompson CJ. The syndrome of inappriopriate diuresis. Best Practice and Research Clinical Endocrinology and Metabolism (2016) 175-178

20. Smith D, Moore K, et al. Downward resetting of the osmotic treshold for thirst in patients with SIADH. American Journal of Physiology Endocrinology and metabolism (2004) 287: E1019-E1023

21. Adrogue H, Madias N. Hyponatremia. The New England Journal of Medicine (2000)

22. Cuesta, M., Garrahy, A., \& Thompson, C. J. (2016). SIAD: practical recommendations for diagnosis and management. Journal of endocrinological investigation, 39(9), 991-1001.

23. Sherlock, M., O'sullivan, E., Agha, A., Behan, L. A., Rawluk, D.,
Brennan, P., ... \& Thompson, C. J. (2006). The incidence and pathophysiology of hyponatraemia after subarachnoid haemorrhage. Clinical endocrinology, 64(3), 250-254.

24. Shepshelovich, D., Leibovitch, C., Klein, A., Zoldan, S., Milo, G., Shochat, T., ... \& Lahav, M. (2015). The syndrome of inappropriate antidiuretic hormone secretion: distribution and characterization according to etiologies. European journal of internal medicine, 26(10), 819-824.

25. Kirby, D., \& Ames, D. (2001). Hyponatraemia and selective serotonin re-uptake inhibitors in elderly patients. International journal of geriatric psychiatry, 16(5), 484-493.

26. Verbalis, J. G., Greenberg, A., Burst, V., Haymann, J. P., Johannsson, G., Peri, A., ... \& Dave, J. (2016). Diagnosing and treating the syndrome of inappropriate antidiuretic hormone secretion. The American Journal of Medicine, 129(5), 537-e9.

27. Egger C, et al. A review of hyponatremia associated with SSRIs, reboxetine and venlafaxine. International Journal of Psychiatry in Clinical Practice (2006) 10(1): 17-26

28. Fenoglio I, et al. Drug induced hyponatremia. About a series of 54 cases notified to the reginal Center of Pharmacovigilance of SaintEtienne. Therapie (2011) 66 (2): 139-148

29. Fonzo-Christe C, Vogt N. Susceptibilty of the elderly patient to hyponatremia induced by selective serotonin reuptake inhibitors. Therapie (2000) 55(5):597-604

30. Brownfields Ms, et al. Neuropharmacological characterization of serotoninergic stimulation of vasopressin secretion in concious rats. Neuroendocrinology (1988) 47(4):277-83

31. Mannesse $\mathrm{C}$, et al. Characteristicks, prevalence, risk factors and underlying mechanism of hyponatremia in elderly patients treated with wntidepressants: a cross-sectional study. Maturitas 76 (2013) 357-363

32. Kirby D, et al. Hyponatremia in elderly psychiatric patients treated with selective serotonin reuptake inhibitors and venlafaxine: a retrospective controlled study in an inpatient unit. International Journal of Geriatric Psychiatry (2002) 17: 231-237

33. Knigge $U$, et al. Histaminergic and catecholaminergic interactions in the central regulation of vasopressin and oxytocin secretion. Endocrinology (1999) 140(8): 3713-9

34. Letmaier $M$, et al. Hyponatraemia during psychopharmacological treatment: results of a drug surveillance programme. International Journal of Neuropsychopharmacology (2012) 15, 739-748

35. Leth-Moller KB, Hansen AH, et al. Antidepressants and the risk of hyponatremia: a Danish register-based population study. BMJ Open (2016)

36. Siegel A, Forte S, et al. Drug-related hyponatremic encephalopathy: rapid clinical response averts life-threatening acute cerebral edema. American Journal of case reports (2016) 17: 150-153

37. Giorlando F, et al. Hyponatraemia: an audit of aged psychiatry patients taking SSRIs and SNRIs. Current Drug Safety (2013) 8(3):175-80

38. Bowen P. Use of serotonin reuptake inhibitors in the treatment of depression in older adults: identifying and managing potential risk of for hyponatremia. Geriatric Nursing (2009) 85-89

39. Barclay T, et al. Citalopram-associated SIADH. The Annals of Pharmacoteraphy (2002) 36: 1558-63

40. Fabian, T. J., Amico, J. A., Kroboth, P. D., Mulsant, B. H., Corey, S. E., Begley, A. E., ... \& Pollock, B. G. (2004). Paroxetine-induced hyponatremia in older adults: a 12-week prospective study. Archives of Internal Medicine, 164(3), 327-332.

41. Arinzon Z, et al. Delayed recurrent siadh associated with ssris. The Annals of Pharmacoteraphy (2002) 36: 1175-7

42. Noohi S, et al. Selective serotonin re-uptake inhibitors and hyponatermia in acutely medically-ill inpatients. Current Drug Safety (2016) 11(2):121-7 
43. Gandhi S., McArthur E., Reiss JP., Mamdani MM., Hackam DG., Weir MA., Garg AX. Atypical antipsychotic medications and hyponatremia in older adults: a population based cohort study. Canadian Journal of Kidney Health and Disease (2016) 3:21

44. Whitten JR, Ruehter VL. Risperidone and hyponatremia: a case report. Ann Clin Psychiatry. 1997;9:181-3

45. Atalay A, Turhan N, Aki OE. A challenging case of syndrome of inappropriate secretion of antidiuretic hormone in an elderly patient secondary to quetiapine. South Med J. 2007;100:832-3

46. Bakhla AK, Guria RT, Kumar A. A suspected case of olanzapine induced hyponatremia. Indian J Pharmacol 2014;46:441-2

47. Dudeja SJ, McCormick M, Dudeja RK. Olanzapine induced hyponatraemia. Ulster Med J. 2010;79:104-5

48. Bhuvaneswar CG, Baldessarini RJ, Harsh VL, Alpert JE. Adverse endocrine and metabolic effects of psychotropic drugs. CNS Drugs. 2009;23:1003-22

49. Rider JM, Mauger TF, Jameson JP. Water handling in patients receiving haloperidol decanoate. Ann Pharmacother 1995; 29: 663-6

50. Ananth J, Lin KM. SIADH: a serious side effect of psychotropic drugs. Int J Psychiatr Med 1987; 16: 401-7

51. Correll CU., Detraux J., De Lepeleire J., De Hert M. Effects of antipsychotics, antidepressants and mood stabilizers on risk for physical diseases in people with schizophrenia, depression and bipolar disorder. World Psychiatry 2015;14:119-136

52. Meulendijks D, Mannesse CK, Jansen PA, Van Marum RJ, Egberts TCG. Antipsychotic-induced hyponatraemia: a systematic review of the published evidence. Drug Saf. 2010;33:101-14

53. Mannesse CK, van Puijenbroek EP, Jansen PA, van Marum RJ, Souverein PC, Egberts TC. Hyponatraemia as an adverse drug reaction of antipsychotic drugs: a case-control study in VigiBase. Drug Saf. 2010 Jul 1;33(7):569-78

54. Shepshelovich D., Schechter A. , Calvarysky B. , Diker-Cohen T., Rozen-Zvi B., Gafter-Gvili Anat. Medication Induced SIADH: Distribution and Characterization According to Medication Class. doi: $10.1111 /$ bcp. 13250

55. Atsariyasinga W., Goldman MB. A systematic review of the ability of urine concentration to distinguish antipsychotic- from psychosisinduced hyponatremia. Psychiatry Research 217 (2014) 129-133

56. Liamis G., Milionis H., Elisaf M., A review of drug-induced hyponatremia, Am J Kidney Dis. 2008 Jul;52 (1):144-53.

57. Zaremba P.D., Białek M., Błaszczyk B., Cioczek P., Czuczwar S.J., Non-epilepsy uses of antiepileptic drugs, Pharmacological Reports 2006, 58, 1-12, ISSN1734-1140.
58. Kuz G. M., Manssourian A., Carbamazepine-Induced Hyponatremia: Assessment of Risk Factors, Ann Pharmacother. 2005 Nov; 39(11):1943-6.

59. Krysiak R., Okopień B., Hiponatremia spowodowana przez karbamazepinę, Pol Arch Med Wewn. 2007; 117 (4): 193-195.

60. Kumar P.N., Gopalakrishnan A., Oxcarbazepine - induced hyponatremia in bipolar disorder: A report of two cases, Indian J Psychiatry. 2016 Apr-Jun; 58(2): 233-234.

61. Patel K.R., Meesala A., Stanilla J.K., Sodium Valproate-Induced Hyponatremia: A Case Report, Prim Care Companion J Clin Psychiatry. 2010; 12(5)

62. Kılıç H., Ekici B., Ergul Y., Keskin S., Uysal S., Lamotrigine-induced SIADH in a child with central diabetes insipidus, J Pediatr Neurosci. 2011 Jan;6(1):89-90.

63. Mewasingh L, Aylett S, Kirkham F, Stanhope R. Hyponatraemia associated with lamotrigine in cranial diabetes insipidus. Lancet. 2000; 356:656

64. Lu X., Wang X., Hyponatremia induced by antiepileptic drugs in patients with epilepsy EXPERT OPINION ON DRUG SAFETY, 2017 VOL. 16, NO.1, 77-87.

65. Dong X., Leppik I.E., White J, Rarick J., Hyponatremia from oxcarbazepine and carbamazepine, Neurology. 2005 Dec 27;65(12):1976-8.

66. Kim Y.S., Kim D.W., Jung K. H., Lee S.T., Kang B.S., Byun J.I., Yeom J.S., Chu K., Lee S.K., Frequency of and risk factors for oxcarbazepine-induced severe and symptomatic hyponatremia, Seizure Volume 23, Issue 3, Pages 167-246 (March 2014).

\section{Correspondence address \\ Ewa Stelmach \\ ul. Głuska 1 \\ 20-439 Lublin \\ tel. 817487320 \\ e-mail: ewastelmach@umlub.pl}

Otrzymano; 02.01.2017

Zrecenzowano: 27.03.2017

Przyjęto do druku: 24.04.2017 